ANNA JAKONIUK-DiALLO

ORCID 0000-0003-3973-8160

Uniwersytet im. Adama Mickiewicza

w Poznaniu

\title{
FORMY KOMUNIKACJI WYKORZYSTYWANE W POROZUMIEWANIU SIĘ OSÓB GŁUCHONIEWIDOMYCH
}

\begin{abstract}
AвSTRACt. Jakoniuk-Diallo Anna, Formy komunikacji wykorzystywane w porozumiewaniu się osób głuchoniewidomych [Forms of Communication with Deaf-Blind People]. Studia Edukacyjne nr 57, 2020, Poznań 2020, pp. 67-75. Adam Mickiewicz University Press. ISSN 1233-6688. DOI: 10.14746/se.2020.57.5

Deafblindness is a disability resulting from simultaneous damage to the two major senses of hearing and sight. It causes limitations in various areas of life, e.g. making contact with other people difficult. The source of communication barriers with deaf people are both cognitive deficits and the different ways of communicating, such as sign language in the palm of the hand, Makaton, Lorm alphabet, etc.
\end{abstract}

Key words: deaf-blind, deafblindness, SKOGN, alternative communication, Lorm alphabet

\section{Wprowadzenie}

Telereceptory, czyli wzrok i słuch, pełnią niezwykle ważną rolę w funkcjonowaniu człowieka. Są źródłem przeważającej liczby informacji o świecie, które do niego napływają. Dostarczając wiedzy o przedmiotach i zjawiskach, umożliwiają spontaniczne nabywanie nowych umiejętności (w procesie uczenia się i socjalizacji), orientację $\mathrm{w}$ przestrzeni i samodzielne poruszanie się, komunikację i współdziałanie, dostęp do wytworów i dóbr kultury. Są więc kluczową determinantą niezaburzonego rozwoju człowieka, warunkującą poczucie bezpieczeństwa, komfortu i kontroli w otoczeniu.

W związku z powyższym, niepełnosprawność sprzężona, wynikająca z jednoczesnej dysfunkcji analizatora wzrokowego i słuchowego, niesie ze sobą szereg następstw. Uszkodzenie obu analizatorów uniemożliwia lub 
w różnym stopniu ogranicza ${ }^{1}$ dostęp do bodźców dźwiękowych i obrazów, redukując tym samym możliwości kompensacji percepcyjnej uszkodzonego wzroku słuchem (jak ma to miejsce w przypadku niewidomych) czy też słuchu wzrokiem (jak u niesłyszących). Konsekwencje, o których możemy mówić w kontekście funkcjonowania osób głuchoniewidomych (OGN) dotyczą trudności w obrębie wielu sfer: dostępu do informacji, nauki i wiedzy, pracy zawodowej, uczestniczenia w życiu kulturalnym i społecznym, orientacji przestrzennej, czy nawet wykonywania czynności dnia codziennego ${ }^{2}$.

Studiując literaturę przedmiotu, nietrudno odnieść wrażenie, że badacze problemu szczególną uwagę poświęcają jeszcze jednej kwestii - umiejętności efektywnego porozumiewania się OGN z otoczeniem, podkreślając jej fundamentalną rolę w rozwoju i życiu każdego człowieka, a także w samym procesie rehabilitacji osoby niepełnosprawnej ${ }^{3}$.

Bariery komunikacyjne wynikające ze specyfiki tego rodzaju niepełnosprawności mają dwojakie podłoże i wiążą się z jednej strony z niespotykanie szeroką gamą form komunikacji, wykorzystywanej przez osoby głuchoniewidome, a z drugiej - z ograniczonymi możliwościami poznawczymi i funkcjonalnymi osób dotkniętych głuchoślepotą.

${ }^{1}$ Wbrew obiegowej opinii, według której głuchoślepota jest utożsamiana ze stanem całkowitej utraty zdolności widzenia i słyszenia, przeważająca liczba osób głuchoniewidomych ma i wykorzystuje resztki słuchu oraz wzroku (lub przynajmniej jednego z tych zmysłów) najczęściej przy wsparciu specjalistycznych urządzeń, np. aparatów słuchowych, implantów ślimakowych, powiększalników elektronicznych itp., które pełnią rolę protezy.

${ }^{2}$ Warto dodać, że aspekt ogólnej sprawności danej osoby jest akcentowany w najczęściej przyjmowanych definicjach dotyczących głuchoślepoty, które można byłoby określić mianem definicji funkcjonalnych (w przeciwieństwie do objaśnień o charakterze medycznym, które uwypuklają kryteria biologiczne - rodzaj i stopień uszkodzenia słuchu i wzroku). Przykładem takiej definicji jest przyjęta przez Towarzystwo Pomocy Głuchoniewidomych (TPG) - jedyną w Polsce organizacją, której działania są ukierunkowane stricte na wsparcie OGN: „Głuchoniewidomą jest osoba, która na skutek jednoczesnego poważnego uszkodzenia słuchu i wzroku napotyka trudności odmienne od spowodowanych wyłącznie uszkodzeniem wzroku i słuchu, widoczne we wszystkich strefach jej funkcjonowania, zwłaszcza w komunikowaniu się, samodzielnym poruszaniu i dostępie do informacji" (Statut Towarzystwa Pomocy Gtuchoniewidomym, 1992); M. Zaorska, Głuchoniewidomi w Polsce - specjalna pomoc, edukacja i rehabilitacja, Olsztyn 2002, s. 20.

3 Zob. G. Kozłowski, Alfabet punktowy dla dtoni głuchoniewidomych, Warszawa 1995; M. Orkan-Łęcka, Wczesne wspomaganie rozwoju komunikacji u dzieci niewidomych i słabo widzacych ze złożona niepetnosprawnościa - model programu edukacyjnego, Rewalidacja, 1999, 2; M. Zaorska (red.), Komunikacja alternatywna osób głuchoniewidomych, Torun 2008; M. Benisz-Stępień, Punkt porozumienia, czyli o komunikowaniu sie z osoba głuchoniewidoma, [w:] Matymi krokami do wielkich celów. W świecie osób głuchoniewidomych, red. M. Białek, Warszawa 2009 i in. 


\section{Zróżnicowanie środowiska OGN}

Jakkolwiek osoby głuchoniewidome stanowią zbiorowość niezbyt liczną ${ }^{4}$, to jest to grupa niezwykle zróżnicowana. Jej członków próbuje się klasyfikować, biorąc pod uwagę dwa podstawowe kryteria:

1) stopień uszkodzenia zmysłów (mogą być to osoby: niesłyszące i jednocześnie niewidome, niesłyszące i słabowidzące, niewidome i słabosłyszące, słabowidzące i słabosłyszące);

2) etap życia, na którym głuchoślepota wystąpiła (osoby z: wrodzonym i manifestującym się od urodzenia uszkodzeniem słuchu oraz nabytym lub ujawnionym w późniejszym okresie uszkodzeniem słuchu, nabytym lub ujawnionym w późniejszym okresie uszkodzeniem słuchu i uszkodzeniem wzroku).

W wyniku połączenia obydwu typologii uzyskujemy aż szesnaście odmiennych kombinacji, na przykład osoby niewidome i słabosłyszące od urodzenia albo słabowidzące od urodzenia $\mathrm{z}$ nabytym niedosłuchem ${ }^{5}$. Tak zaproponowany podział nie odzwierciedla jednak dostatecznie zróżnicowania populacji, gdyż w ramach jednej kombinacji spotyka się OGN funkcjonujące na różnych płaszczyznach lepiej bądź słabiej, a ma na to wpływ wiele dodatkowych czynników. Wśród nich wymienić można: etiologię niepełnosprawności, ewentualne współwystępujące wady i schorzenia, indywidualne cechy osobowościowe i status socjoekonomiczny konkretnej jednostki, czy dostęp do sprzętu technicznego ułatwiającego odbieranie bodźców ${ }^{6}$.

\section{Zróżnicowanie metod komunikacji OGN}

Tak szerokie zróżnicowanie poziomu możliwości poznawczych OGN ma swoje bezpośrednie odbicie w sposobach ich komunikowania się. Podejście praktyczne wymusza zatem wyodrębnienie poszczególnych podgrup także

${ }^{4}$ Małgorzata Książek (2013) poruszając temat liczebności populacji OGN w Polsce, podkreśla, że jedyne statystyki w tym zakresie prowadzi TPG, którego ewidencja obejmuje „ok. 2400 osób z jednoczesnym uszkodzeniem słuchu i wzroku. Daje to średnio ok. 150 osób głuchoniewidomych na województwo i ok. 6-7 na powiat; to pokazuje, jak rzadką niepełnosprawnością jest głuchoślepota. Bazując na danych statystycznych z innych krajów, szacujemy, że w Polsce jest znacznie więcej osób głuchoniewidomych, niż liczy nasza ewidencja; co najmniej 7-8 tys. Oznaczałoby to, ze TPG dotarło do zaledwie 30-40 procent z nich (...)".

${ }^{5}$ M. Zaorska, Gtuchoniewidomi w Polsce, s. 24; M. Książek, Wszystko, co powinieneś wiedzieć o guchoślepocie [w:] Matymi krokami do wielkich celów, s. 8-9.

${ }^{6}$ M. Benisz, Komunikacja przez dotyk - gtuchoniewidomi, [w:] Alternatywne i wspomagajace metody komunikacji, red. J.J. Błeszyński, Kraków 2006, s. 332. 
na tej płaszczyźnie, a jedynym wyznacznikiem jest w tym przypadku prymarny sposób komunikacji. Idąc tym tropem, można wyróżnić trzy zasadnicze społeczności wśród głuchoniewidomych w Polsce ${ }^{7}$ :

1. OGN, u których rozwój umiejętności komunikacyjnych jest zaburzony, nie opanowały dobrze ani języka fonicznego, ani wizualno-przestrzennego i wymagają innych metod porozumiewania się (osoby głuchoniewidome od urodzenia lub wczesnego dzieciństwa, przeważnie z dodatkowymi uszkodzeniami czy niepełnosprawnościami, szczególnie intelektualnymi);

2. OGN, dla których pierwszym i podstawowym językiem komunikacji jest ogólnonarodowy literacki język polski (m.in. osoby, które wcześniej słyszały, ale straciły słuch);

3. OGN, dla których pierwszym i podstawowym językiem jest język migowy (najczęściej osoby niesłyszące, ściśle związane z kulturą Głuchych).

W sytuacji, kiedy dziecko głuchoniewidome nie jest w stanie opanować biegle żadnego tradycyjnego systemu komunikacji, wówczas oferuje się im metody wspomagające lub zastępujące mowę dźwiękową (tzw. AAC - ang. augmentative and alternative communication), które umożliwiają porozumiewanie się z otoczeniem. Mogą to być zarówno systemy gestowe (np. Makaton), jak i graficzne o różnym stopniu ikoniczności (od realnych przedmiotów, ich fragmentów, przez miniatury, fotografie, rozmaite rysunki, do symboli Blissa). Metody te znacznie poszerzają możliwości komunikacyjne dziecka, a ich dobór jest kwestią bardzo indywidualną, uzależnioną od stanu jego wzroku, słuchu, możliwości motorycznych i poziomu rozwoju umysłowego 8 .

Drugą grupę stanowią użytkownicy języka ogólnopolskiego, wśród których notujemy największe zróżnicowanie sposobów przekazywania informacji. Wykorzystują one kanał słuchowy, wzrokowy lub/oraz dotykowy. Osoby niedosłyszące, korzystając z resztek słuchu, posługują się najczęściej mową artykułowaną. Pomagają im w tym takie urządzenia, jak: aparaty słuchowe, implanty ślimakowe, pętle induktofoniczne albo systemy FM. Osoby posługujące się jeszcze wzrokiem odczytują mowę z ust i czytają teksty pisane (odręcznie bądź np. na komputerze), nierzadko korzystając z różnych pomocy optycznych, w tym: okularów, lup, różnego rodzaju powiększalników. Niewidomi biegle znający pismo brajla nie tylko piszą i odczytują je w standardowy sposób, lecz mogą także odbierać komunikaty dzięki literom wystukiwanym przez nadawcę bezpośrednio na palcach ich dłoni w dwóch wariantach brajla do palców:

\footnotetext{
${ }^{7}$ M. Benisz-Stępień, Punkt porozumienia, s. 23-25.

${ }^{8}$ M. Książek, Dziecko głuchoniewidome od urodzenia, Warszawa 2003, s. 139-143.
} 
1) jednoręcznego - polega na dotykaniu odpowiednich punktów na palcach wskazującym i środkowym (których paliczki odpowiadają tzw. sześciopunktowi) w sekwencjach charakterystycznych dla poszczególnych liter alfabetu brajla;

2) dwuręcznego - gdzie po trzy palce (wskazujący, środkowy i serdeczny) obu dłoni odpowiadają kolejno sześciu klawiszom brajlowskiej maszyny do pisania9.

Dla innych OGN, z tej grupy, podstawą komunikacji mogą stać się litery czarnodrukowe alfabetu łacińskiego, kreślone na dłoni w kierunku odbiorcy tak, by ten odczytywał je jak z książki ${ }^{10} l u b$ metoda alfabetu punktowego do dłoni, która opiera się na lokalizacji wszystkich liter, cyfr i podstawowych znaków interpunkcyjnych i matematycznych w określonych miejscach lewej dłoni ${ }^{11}$.

Wśród OGN znaczący odsetek stanowią osoby funkcjonalnie głuche, których podstawowymi i naturalnymi sposobami porozumiewania się są: język wizualno-przestrzenny (w naszym kraju PJM, czyli Polski Język Migowy) oraz daktylografia. Jeżeli mamy do czynienia z osobami niedowidzącymi, to mogą one efektywnie posługiwać się nimi w tradycyjny sposób. W sytuacji utraty wzroku nadal w komunikacji stosują one język wizualno-przestrzenny (i alfabet palcowy), przy czym zmieniają drogę odbioru komunikatów ze wzrokowej na dotykową, co wymaga od nich ciągłej kontroli przestrzeni, w której prezentowane są znaki migowe, a zatem wymusza stały, bezpośredni kontakt dłoni OGN z dłońmi nadawcy (,język migowy do ręki”).

Niezwykle rozbudowany i zróżnicowany konglomerat form porozumiewania się, z jakim mamy do czynienia w przypadku populacji osób z jednoczesnym uszkodzeniem wzroku i słuchu (tzw. SKOGN - sposoby komunikacji osób głuchoniewidomych), jest najpoważniejszym źródłem trudności i barier komunikacyjnych w kontakcie z osobami spoza tej społeczności (relatywnie niewielu pełnosprawnych zna chociażby język migowy), jak i na-

${ }^{9}$ K. Klugiewicz, H. Rudomska, Jędnoręczny i dwuręczny brajl do palców oraz Kreślenie na dłoni liter drukowanych, [w:] Komunikacja alternatywna osób głuchoniewidomych, red. M. Zaorska, Toruń 2008, s. 152-154.

${ }^{10}$ Tamże, s. 155-156.

${ }^{11}$ Jako uzupełnienie spisu metod wykorzystywanych do odbioru języka ogólnonarodowego, warto wspomnieć także o tej, która jako pierwsza była proponowana OGN do dotykowego odbioru mowy - jest to metoda Tadoma (posługiwała się nią m.in. H. Heller), która bazuje na zdobyciu umiejętności odróżniania za pomocą palców układu narządów artykulacyjnych, ruchów mięśni twarzy, drgań krtani podczas wymawiania poszczególnych liter (słów). OGN kładzie kciuk na wargi osoby mówiącej, a pozostałymi, lekko rozwartymi palcami obejmuje część jej twarzy - od łuku jarzmowego do szyi (M. Zaorska, Głuchoniewidomi w Polsce, s. 62); G. Kozłowski, Alfabet punktowy dla dłoni. 
leżącymi do niej. Często ma się do czynienia z sytuacją, w której dwie OGN nie są $w$ stanie rozmawiać ze sobą bezpośrednio, gdyż porozumiewają się w odmienny sposób i w związku z tym zmuszone są do skorzystania podczas interakcji z pomocy osoby trzeciej w roli tłumacza. Problem ten dotyczy także specjalistów (rehabilitantów, psychologów itp.) chcących pracować z OGN; niewielu z nich potrafi sprawnie posługiwać się wszystkimi metodami używanymi wśród tej zbiorowości. ${ }^{12}$

Niejako w odpowiedzi na akcentowany powyżej problem, Towarzystwo Pomocy Głuchoniewidomym (TPG) od kilku lat propaguje (zapożyczony z krajów Europy Zachodniej i zaadaptowany do polskiej wersji przez Małgorzatę Benisz) tak zwany alfabet Lorma, czyli system punktów, linii i znaków dotykowych umieszczanych na dłoni, którego schemat stał się już jednym z atrybutów organizacji.

Nazwa alfabetu pochodzi od pseudonimu artystycznego jego twórcy Heinricha Landesmanna (żyjącego w XIX w. pisarza, eseisty, dziennikarza), który publikował pod nazwiskiem Heryonymus Lorm. Jako szesnastoletni młodzieniec stracił słuch, a blisko 20 lat później także wzrok i do końca życia był osobą całkowicie głuchoniewidomą, jednak wciąż aktywną zawodowo. Aby móc wyrażać swoje myśli i komunikować się z otoczeniem, opracował (wraz z córką) alfabet dotykowy, który do dnia dzisiejszego jest znany i wykorzystywany między innymi w Niemczech, Austrii, Szwajcarii, Belgii, Czechach i Polsce.

Najistotniejszą spośród licznych zalet ${ }^{13}$ tej metody jest jej uniwersalność. Głuchoniewidomi traktują Lorma jako jedyną neutralną formę porozumiewania się, bez względu na środowisko, z jakiego pochodzą i język, jakim się na co dzień posługują. Dzięki niemu mogą rozmawiać ze sobą bez pomocy tłumacza, gdyż metoda ta jest odpowiednia i dostępna dla każdego, kto potrafi formułować komunikaty za pomocą któregokolwiek alfabetu: łacińskiego, brajla, czy też daktylografii. Nie wymaga w zasadzie żadnych specjalnych warunków ani sprzętów, a wręcz rozwiązuje wiele problemów z nimi związanych. Można z niej korzystać w każdych okolicznościach, w których inne metody zawodzą: $w$ ciemności, tłumie, podczas marszu, tańca, w teatrze, kinie, kościele, na konferencji i tym podobnych ${ }^{14}$.

${ }^{12}$ M. Benisz, Komunikacja przez dotyk, s. 339-340.

${ }^{13}$ Alfabet Lorma cechuje się m.in.: skutecznością, małym ryzykiem błędu, jednoznacznością, prostotą, dyskrecją i komfortem. Nie jest jednak oczywiście metodą idealną i pozbawioną wad. Po pierwsze, nie jest w stanie oddać ekspresji wypowiedzi, a po drugie - uzyskanie biegłości w posługiwaniu się nią (które pozwala docenić pełnię zalet) wymaga dużo wysiłku i ćwiczeń (tamże, s. 166).

${ }^{14}$ Zob. M. Benisz, Komunikacja przez dotyk, s. 343-350; J. Celmer-Domańska, Metoda Lorma, [w:] Komunikacja alternatywna, s. 162-170. 


\section{Dodatkowe trudności w porozumiewaniu się z OGN i ich przezwyciężenie}

Jednoczesne uszkodzenie wzroku i słuchu wymusza nie tylko używanie $\mathrm{w}$ stosunku do OGN często jedynej, preferowanej formy porozumiewania się, ale również rzutuje na odmienność całego procesu komunikacji, jakość podejmowanych interakcji, charakterystyczne zachowania i zjawiska $\mathrm{w}$ ich obrębie. Wcielając się $\mathrm{w}$ rolę interlokutora OGN, musimy być świadomi ich ograniczeń i potrzeb, aby móc dostosować się do nich w taki sposób, aby rozmowa przebiegła jak najefektywniej.

Do elementów najbardziej dezorganizujących i utrudniających proces komunikacji z OGN możemy zaliczyć to, że:

- występują u nich problemy z aktywnym włączeniem się $\mathrm{w}$ rozmowę, śledzeniem jej toku, orientowaniu się w temacie dyskusji, kto teraz mówi itp.;

- odbiór informacji bywa niepełny i wymaga ciągłego domyślania się, dopowiadania, co może być przyczyną nieporozumień, mylnych interpretacji, utraty sensu komunikatu;

- porozumiewanie się z OGN trwa wolniej;

- obserwujemy u nich brak lub opóźnienie odpowiedniej reakcji lub nawet ekspresji;

- są najczęściej jedynie biernymi uczestnikami rozmowy ${ }^{15}$.

Aby zapewnić odpowiedni komfort i skuteczność przebiegu interakcji, warto między innymi dokonać oceny otoczenia pod kątem potrzeb i możliwości wzrokowo-słuchowych OGN, przemyśleć klarowność przekazu, starać się stale przekazywać cały kontekst sytuacyjny, zapobiegać niedomówieniom i dbać o pozytywną atmosferę. Komunikacja z ludźmi dotkniętymi głuchoślepotą wymaga zazwyczaj od pełnosprawnego rozmówcy większej niż zwykle cierpliwości, empatii, elastyczności, wyostrzonej koncentracji i wyobraźni. W jego gestii leży bowiem poszukiwanie różnych udogodnień w nawiązaniu kontaktu i podtrzymywaniu rozmowy - w zależności od tego, jakie uszkodzenie (wzroku czy słuchu) dominuje u OGN oraz który sposób komunikacji jest przez nie preferowany. Osobie niesłyszącej odczytywanie mowy z ust ułatwia, na przykład dobre oświetlenie i utrzymywanie kontaktu wzrokowego, natomiast utrudnia lub uniemożliwia wykonywanie przez rozmówcę zbędnych ruchów głową czy chodzenie po pokoju. Z kolei, dla osób wykorzystujących resztki słuchu istotne jest stworzenie odpowiednich warunków akustycznych i wyeliminowanie dźwięków zakłócających ${ }^{16}$.

\footnotetext{
${ }_{15}$ M. Zaorska, Gtuchoniewidomi w Polsce, s. 69.

${ }^{16}$ Zob. M. Benisz-Stępień, Punkt porozumienia, s. 28-34.
} 


\section{Podsumowanie}

Niepełnosprawność w postaci jednoczesnego uszkodzenia zmysłu wzroku i słuchu prowadzi do poważnych konsekwencji. Jest źródłem wielu ograniczeń, które zakłócają prawidłowe funkcjonowanie człowieka w wielu obszarach jego życia, w tym komunikacji z otoczeniem. Głuchoślepota o różnym nasileniu może komplikować lub całkowicie uniemożliwiać efektywne porozumiewanie się z innymi ludźmi, szczególnie przy wykorzystaniu mowy dźwiękowej. Natomiast mnogość metod komunikacji, preferowanych przez osoby głuchoniewidome, negatywnie wpływa na kontaktowanie się nawet w obrębie własnego środowiska. Z tych względów zdarzają się sytuacje, w których OGN wymagają specjalnego wsparcia w zakresie kontaktu i funkcjonowania w środowisku społecznym (np. wizyta u lekarza czy w urzędzie). Od wielu lat, w ramach działalności TPG, pomoc taką świadczą przeszkoleni tłumacze - przewodnicy. Dzięki ich asyście osoby dotknięte głuchoślepotą, bez względu na swoje ograniczenia, mogą dotrzeć w wybrane miejsce i skutecznie porozumiewać się z innymi ludźmi ${ }^{17}$.

\section{BIBLIOGRAFIA}

Benisz M., Komunikacja przez dotyk - gtuchoniewidomi, [w:] Alternatywne i wspomagajace metody komunikacji, red. J.J. Błeszyński, Kraków 2006.

Benisz-Stępień M., Punkt porozumienia, czyli o komunikowaniu się z osoba głuchoniewidoma, [w:] Małymi krokami do wielkich celów. W świecie osób głuchoniewidomych, red. M. Białek, Warszawa 2009.

Celmer-Domańska J., Metoda Lorma, [w:] Komunikacja alternatywna osób głuchoniewidomych, red. M. Zaorska, Torun 2008.

Klugiewicz K., Rudomska H., Jędnoręczny i dwuręczny brajl do palców oraz Kreślenie na dłoni liter drukowanych, [w:] Komunikacja alternatywna osób głuchoniewidomych, red. M. Zaorska, Torun 2008.

Kozłowski G., Alfabet punktowy dla dtoni głuchoniewidomych, Warszawa 1995.

Książek M., Dziecko głuchoniewidome od urodzenia, Warszawa 2003.

Książek M., Wszystko, co powinieneś wiedzieć o głuchoślepocie, [w:] Małymi krokami do wielkich celów. W świecie osób głuchoniewidomych, red. M. Białek, Warszawa 2009.

Książek M., Niepetnosprawność wzrokowa i wzrokowo-stuchowa, jako przesłanki dyskryminacji, 2013; online: http://www.tea.org.pl/userfiles/file/Seminaria, [dostęp: 25 X 2013].

Statut Towarzystwa Pomocy Gtuchoniewidomym, 1992; online: www.tpg.org.pl, [dostęp: 26 X 2013].

Orkan-Łęcka M., Wczesne wspomaganie rozwoju komunikacji u dzieci niewidomych $i$ stabo widzacych ze złożona niepetnosprawnościq - model programu edukacyjnego, Rewalidacja, 1999, 2.

17 Wprowadzona w 2011 roku Ustawa o języku migowym i innych środkach komunikowania się nakłada m.in. na urzędy obowiązek zapewnienia osobom głuchoniewidomym tłumacza SKOGN. 
Ustawa z 19 sierpnia 2011 r. o języku migowym i innych środkach komunikowania się; online: www.isap.sejm.gov.pl, [dostęp: 28 X 2013].

Zaorska M., Gtuchoniewidomi w Polsce - specjalna pomoc, edukacja i rehabilitacja, Olsztyn 2002. Zaorska M. (red.), Komunikacja alternatywna osób głuchoniewidomych, Toruń 2008.

\section{Skróty}

OGN - osoby głuchoniewidome

SKOGN - sposoby komunikowania się osób głuchoniewidomych

TPG - Towarzystwo Pomocy Głuchoniewidomym 